\title{
Gertrude Cox in Egypt: A Case Study in Science Patronage and International Statistics Education during the Cold War
}

\section{Patti W. Hunter}

Westmont College

\section{Argument}

Gertrude Cox, first chair of North Carolina State University's Department of Experimental Statistics, worked as a consultant for the Ford Foundation to Cairo University's Institute of Statistical Studies and Researches in 1964. An analysis of this work provides a case study in the internationalization of the statistics profession, the systems of patronage available to scientists in the second half of the twentieth century, and the history of women in science. It highlights some of the complexities in the process of internationalization in science, showing that even when scientists cross national boundaries to promote their discipline, they may have as a goal the advancement of their own nationalistic interests, or those of their patrons. In documenting Cox's commitment to serving her professional community, this case study will show that some particularly feminine qualities of Cox's approach to her work enabled her to accomplish what her male colleagues tried unsuccessfully to do.

\section{Introduction}

In April 1966, Gertrude Cox, the retired director of the University of North Carolina's Institute of Statistics, gave a talk to her local chapter of the American Statistical Association (ASA), entitled, "Education in Statistics." Cox had spent the 1964-65 academic year living in Cairo, Egypt, serving as a consultant for the Ford Foundation to Cairo University's Institute of Statistical Studies and Researches (ISSR). At this ASA banquet, Cox described some of her experiences in Egypt, reflecting on what she had learned about the needs of the statistics programs in the country, comparing them to those in the United States. Cox included some comments about the historical development of the discipline in these remarks. "The status of statistics in the rapidly developing countries," she observed, "is not too different from what my generation experienced in the nineteen twenties" in the United States (Cox 1966a, in Cox Papers).

Cox, born in 1900, was a member of the generation that saw the establishment of statistics as a discipline in the United States. She received her training and began her career as a statistician during the 1930s and 1940s - the American statistical community's formative years - just as such training and careers were becoming possible. As the first 
recipient of a degree in statistics from Iowa State College, as the first head of the first university department of statistics in the United States (North Carolina State College), and as an active leader of professional statistics organizations throughout the world, Gertrude Cox's life reveals much about the early years of statistics in the United States.

Here, however, her experiences and contributions will be analyzed not in the context of the birth of the American statistics community, nor for the purpose of providing a particular perspective on the life of Cox herself. Rather, Cox's involvement with the ISSR in Egypt and the events leading up to her work there will serve as a case study of several broader issues in the history of science. Cox was a prominent statistician from the United States, advising a nascent university program in a developing country during the Cold War period. Funded by a major philanthropic foundation, her work in Cairo formed part of a larger network of efforts to promote research and university teaching of statistics. This network included agencies of the US government and the United Nations, international academic societies, and American universities. Moreover, Cox was one of very few women in the United States taking a leading role in the promotion of science during the 1960s. The episode examined here, then, provides evidence for several claims and suggests lines of further research relative to the internationalization of the statistics profession, the systems of patronage available to scientists in the second half of the twentieth century, the history of women in science, and the nature and practice of the discipline of statistics during this period.

A number of historical studies in the last twenty years have explored the process by which scientists have exchanged ideas and promoted their disciplines across national boundaries (Parshall and Rice 2002). In their book, Denationalizing Science: The Contexts of International Scientific Practice, editors Elisabeth Crawford, Terry Shinn, and Sverker Sörlin have argued that today, scientific activity involving people and resources from more than one country (what they call transnational science) is replacing activity based in a single nation. Moreover, they point to a diminishing role in scientific funding from the state as funding from industry increases, and suggest that these trends indicate a denationalizing of science, in which national distinctions are becoming increasingly irrelevant for scientific practice (Crawford et al. 1993).

The discussion that follows provides an example of transnational scientific exchange that had as its specific goal the strengthening of a particular national scientific community and enterprise. This promotion of Egyptian science occurred, however, in the context of other national and international agendas - in particular, the Cold War foreign policy of the United States and the UN's efforts to address issues of economic development. This case study, then, highlights some of the complexities in the process of internationalization in science during the second half of the twentieth century. It shows that even when scientists cross national boundaries to promote their discipline, they may have as a goal the advancement of their own nationalistic interests, or those of their patrons. Those interests may be broadly political, as in the Cold War battles for control over the so-called Third World. More narrowly, they may be discipline-related, expressed in efforts to move from the periphery to the center of the 
disciplinary network. The events documented here show that by the 1960s, the United States occupied an important place in the center of the academic statistics profession, and that countries such as Egypt sought places near that center for themselves.

Closely tied to the process of internationalization are questions about the systems of patronage that supported the statistics profession during this period. The Ford Foundation established the program for which Cox worked in Cairo, but similar projects received direction and aid from the United Nations, the US Census Bureau, the US Agency for International Development, American universities, and the Rockefeller Foundation. These patrons of statistics play only a supporting role in this study, but the narrative analyzed here suggests that this particular scientific discipline could be a starting point for further explorations of these patrons themselves, as well as a fruitful source of information about the funding of scientific research in the post-World War II period.

Robert E. Kohler explores the role played by American philanthropic foundations in funding science during the first half of the twentieth century in his Partners in Science: Foundations and Natural Scientists, 1900-1945 (Kohler 1991). He describes the changing place of science funding in the Carnegie and Rockefeller foundations up through World War II, uncovering important aspects of both the history of science and the history of American foundations. This case study suggests that philanthropic foundations continued to play a significant role in science patronage after World War II. It also reveals some links between foundation and federal funding of science, and some connections between that patronage and national and international political concerns emerging after the war. It demonstrates that some statisticians in the United States and elsewhere found ways to get financial support for their work by tying it to the promotion of economic development abroad. It also provides evidence for some tension between those pragmatic aspects of the discipline that appealed to such donors as the Ford Foundation and the more theoretical work some statisticians favored.

Finally, this case study documents the unusual success of a woman scientist whose career nevertheless exhibited some of the typical challenges faced by American women in science during the twentieth century. In her two volumes of Women Scientists in America, Margaret W. Rossiter documents the processes that gave women places in the scientific communities of the United States from the nineteenth century to the equal rights legislation of the early 1970s (Rossiter 1982; idem 1995). She describes strategies women used to acquire those places and their changing status in universities, government, and industry. She explores the broader landscape of the history of American science in light of the experiences of women.

Cox's professional activities (mentioned in the second volume) spanned the two periods covered by Rossiter's books. Her education and early career before 1940 exemplify the limitations and barriers women confronted in academic science, as well as some of their responses. Cox's success building statistics research and teaching programs at the universities in North Carolina and her role in promoting such programs abroad make her "exceptional" after 1940. This case study will document Cox's commitment 
to serving her professional community and the contribution that commitment made to her success in Egypt. In particular, it will show that some particularly feminine qualities of Cox's approach to her work enabled her to accomplish what her male colleagues tried unsuccessfully to do.

Gertrude Cox's trip to Egypt in 1964 raises questions in such diverse areas - science patronage, the internationalization of science, political concerns, women in science - in part because of a diversity in the discipline of statistics itself in the 1960s. Thus, as a case study, the account below contributes to the history of statistics in general, and to the history of the statistics community in the United States in particular. In previous work, I have described the process by which mathematical statisticians in the US created a professional community for themselves, distinguishing their interests in theory from the applications of statistics that were tools for, among others, social scientists in the early twentieth century (Hunter 1996). The emergence of mathematical statistics (both as a scientific discipline and a profession) was only one aspect of the history of statistics in the twentieth century. As researchers in agriculture, medicine, economics, sociology, and engineering - to name just a few disciplines - learned to use and develop the increasingly sophisticated tools of statistics, professional communities supporting these diverse interests sprang up. They published research journals, created academic societies, and carved out their own niches in government, industry, and academia. The story of Gertrude Cox's work in Cairo suggests some ways in which that diversity shaped the statistics profession in the United States and internationally.

The narrative that follows will consider Cox's work in Egypt and the circumstances that led her there, in order to establish the validity of the broader claims outlined above. This example of one statistician's work in a single country on behalf of the Ford Foundation is not meant to carry the whole burden of an argument for these claims. Rather, as a case study, this paper lays the groundwork for research into other examples that would give additional support to the claims made here, allowing them to be stated more broadly and established more conclusively.

\section{Gertrude M. Cox: Education and Career}

Gertrude Cox was born in 1900 in Dayton, Iowa, and attended Iowa State College, receiving a bachelor's degree in mathematics in 1929 and a master's degree in statistics in 1931. ${ }^{1}$ After two years studying psychology at the University of California, Berkeley, Cox returned to Iowa State as an assistant to George Snedecor, the director of the college's statistics program. She became a Research Assistant Professor in 1939 (Lush 1972; Bancroft 1982; Anderson 1990; Anderson et al. 1979). ${ }^{2}$ As a researcher and

\footnotetext{
${ }^{1}$ Cox received an honorary D.Sc. from Iowa State in 1958.

2 The mathematics department granted graduate degrees in statistics until Iowa State established its department of statistics in 1947. The first Ph.D. in statistics at Iowa State was earned by Holly C. Fryer in 1940.
} 
teacher in the Statistical Laboratory, Cox worked in the field of experimental design. She later co-authored a textbook on the subject with William G. Cochran, who joined the statistics staff at Iowa State in 1939 and followed Cox to North Carolina in 1946 (Cochran and Cox 1950). ${ }^{3}$

Cox went to North Carolina State College in 1940 when the institution established its Department of Experimental Statistics. The department, with Cox as its first chair, provided consulting for researchers and service courses for students in the School of Agriculture, in addition to granting degrees (Nourse and Greenberg 1978). As demand for the consulting and computing services grew, the department became part of a college-wide Institute of Statistics in 1944, with Cox as its director. Two years later, Cox succeeded in having the Institute made a division of the state's university system and in securing funds to start a Department of Mathematical Statistics at the University of North Carolina, Chapel Hill (UNC). ${ }^{4}$ As director of the Institute, Cox hired Harold Hotelling to chair the Department of Mathematical Statistics. Hotelling, a prominent member of the American mathematical statistics community who had been teaching statistics in the economics department at Columbia University, served as an associate director of the Institute under Cox, along with William G. Cochran, who left Iowa State to chair the Department of Experimental Statistics in Raleigh (ibid., 176). ${ }^{5}$

Cox remained in her position as director of the Institute of Statistics until 1960 when she became the first director of the Statistics Research Division of the newly created Research Triangle Institute, a non-profit organization providing contract research to government and industry (Larrabee 1991). In 1964, she left this position to begin her consulting trip to Egypt. That trip did not mark the beginning of Cox's international work in statistics nor her first contribution outside of North Carolina to the promotion of the statistics profession. Indeed, her role in the statistics community had extended beyond the borders of North Carolina and the United States from the early years of her career.

She was an active member of both the American Statistical Association and the Institute of Mathematical Statistics (IMS). Both organizations recognized the importance of her contributions to the statistics community and elected her a fellow in 1944. Cox served on the governing boards of the IMS and the ASA in the late 1940s and was president of the ASA in 1956. She edited the international journal Biometrics from 1945 to 1955, helping to launch the Biometric Society in 1947.

Cox's prominence as a scientist and administrator was an unusual accomplishment for a woman in the United States during the decades following World War II. The field

\footnotetext{
${ }^{3}$ On Cochran, see the brief biography and discussions of his contributions to statistics in Rao and Sedransk 1984.

${ }^{4}$ In 1931, the state of North Carolina united its three institutions of higher education - the University of North Carolina in Chapel Hill, North Carolina State College of Agriculture and Engineering in Raleigh, and the North Carolina College for Women in Greensboro - into a single system, known then as the University of North Carolina. For the details of the events surrounding this unification, consult Wilson 1964.

${ }^{5}$ For biographical information on Hotelling, see Madow 1960 and Neyman 1960.
} 
of statistics, like many other sciences, flourished and expanded as funding increased in the postwar era, and as historian Margaret Rossiter has pointed out, Cox "got a good start during World War II and just kept on growing and building as her field broadened and the federal and other funding blossomed. She not only managed to ride the wave of Big Science in the 1950s and 1960s but to be enough ahead of it to help shape the form it took and the impact it had on her university, field, and region" (Rossiter 1995, 203-204).

Although Cox's professional success from the time she moved to North Carolina State was unusual, the early stage of her career reflects many of the issues facing women in academia (and in science in particular) in the first half of the twentieth century. ${ }^{6}$ She entered college at age 25, after a brief pursuit of church-based social work. Although she taught a graduate course in experimental design at Iowa State from 1934 to 1939 and published seven papers between 1931 and 1939, she did not receive her promotion from Research Assistant to Research Assistant Professor until 1939.

This appointment - still not a regular faculty position in the college - came a year after a joint project with the US Department of Agriculture provided funds for the expansion of the Statistical Laboratory and the hiring of two new staff members, Charles P. Winsor, who came from Harvard with a Ph.D. in physiology, and William Cochran, who had spent the previous four years working at Rothamsted Experimental Station in England with Frank Yates and who had master's degrees from Glasgow University and Cambridge (Anderson 1980). So, although arguably as qualified as others hired at the time, Cox was passed over for advancement. For the first nine years of her career, she fell among the women scientists Rossiter describes as "lost in labyrinthine passages that worked in a variety of ways to ... keep them in low ranks, pay them lower salaries, and direct them to adjunct positions as research associate" (Rossiter 1982, 216).

Rossiter acknowledges that while "it has been possible to document this phenomenon of discrimination ... it is more difficult to penetrate the mentality that perpetrated it." She suggests that intense competition for prestige among men in academia and the precarious "economic and social position of the professoriate" in the 1920s and 1930s often prevented women from getting equitable treatment (ibid.). What limited Cox in particular during that first decade of her career is difficult to document. Until the Laboratory's expansion in 1938, she was one of three staff members working under George Snedecor. He had been her graduate advisor, and she coauthored papers with him, did some of the statistical analysis for his agricultural research, and supervised the staff performing the calculations needed in the research (Snedecor and Cox 1935; Snedecor 1936, 699-700). ${ }^{7}$ In Snedecor, Cox had a mentor and a sort of benefactor.

\footnotetext{
${ }^{6}$ Perhaps surprisingly, neither her own papers nor the writings of others who mention Cox seem to raise gender issues explicitly or to go beyond brief acknowledgment of the fact that her accomplishments were unusual for a woman.

${ }^{7}$ Cox's role in supervising the computing services points to another issue in the history of women in science with connections to the history of statistics. Before the widespread use of electronic computers in statistical research,
} 
She may also have experienced what Rossiter describes as one of the "pitfalls to this kind of personal patronage." Such support sometimes "led to the unfortunate assumption (for female but apparently not for male protégés) that the young woman was merely helping the professor with his research rather than doing her own work" (Rossiter 1982, 186).

Whether Cox felt trapped by Snedecor's sponsorship or deprived of proper credit for her contributions is not clear. In the obituary of Snedecor that she coauthored, Cox expresses "her sincere personal appreciation of his great intelligence, patient instruction, high standards of excellence, wise counsel, and friendship" (Cox and Homeyer 1975, 266). Yet she also quotes him announcing (inexplicably, according to Cox), "All smart women get married," when she reported some concerns she had about the computing work she was supervising (ibid., 280). Cox described Snedecor as "a gallant southern gentleman, popular with the women and favored [sic] pretty girls in his classes." She quotes Cochran's remark that "If I wanted to speak to George [Snedecor] at a large social gathering, my strategy was to look for the three prettiest girls at the affair. George would be found sitting talking to one of them, or perhaps to all three" (ibid., 287).

Snedecor may have simply been blind to the possibility that a woman could advance professionally in what was then very much a man's world. When he was asked to recommend someone to head the Department of Experimental Statistics being created at North Carolina State College, "he listed the names of five young men that he recommended, then he half-heartedly added, 'If you would consider a woman, I know of no one better qualified than Gertrude M. Cox"” (ibid., 284). ${ }^{8}$ According to one account, he made this addition only after Cox asked him why the list did not include her name (Anderson et al. 1979, 4). ${ }^{9}$

If her assertiveness resulted in her recommendation to NC State, her talents, energy, and personality made her successful there and resulted in the creation of one of the most highly regarded university statistics programs in the United States. The experience and prestige she earned through this accomplishment gave her opportunities to advise and encourage other university administrators and statisticians in the United States and abroad as they sought ways to develop statistics research and education programs in their own institutions.

Cox's trips abroad often coincided with her attendance at the biennial meetings of the International Statistical Institute (ISI). Founded in 1885, the Institute consisted of

\footnotetext{
the job of performing the long calculations needed in that research was just the sort of tedious, anonymous "women's work" that had created jobs for women in astronomy in the late nineteenth and early twentieth centuries (see Rossiter 1982, 53-55). Rossiter discusses the place of women in computer science in the 1960s, but a detailed analysis of women's participation in the (human) computing side of statistics is needed. For some information on the history of human computers, see Grier 2005.

${ }^{8}$ It is not clear if Snedecor meant that Cox was the most qualified among all statisticians he would recommend or only among the women. Moreover, these may not be his precise words (see footnote below).

${ }^{9}$ Here, Snedecor's letter is quoted as "Of course if you would consider a woman for this position I would recommend Gertrude Cox of my staff."
} 
a limited number of elected members (150 in 1885), government officials responsible for their nations' data-collection, and academic researchers renowned for their contributions to statistics. Cox was elected a member of the ISI in 1948. At the time, she was one of twenty American members (out of a total of 200), and the only woman. ${ }^{10}$ She served as the organization's treasurer from 1955 to 1962 , and then as the chair of the ISI's Education Committee. Through her work for the ISI, and particularly for the Education Committee, Cox developed her interest in the Institute of Statistical Studies and Researches, and the personal and professional contacts that led to her visit to Cairo in 1964. Some details of the ISI's history will explain how statisticians' interest in internationalizing their profession had evolved since the late nineteenth century.

\section{The ISI Education Committee: An International Agenda}

When it was founded, the ISI had focused on improving and standardizing governments' methods of collecting and organizing demographic and economic data. By the time Cox was elected in 1948, two major alterations to the landscape in which the ISI operated would affect Cox's participation in the coming decades. First, changes in the discipline of statistics, both in the body of knowledge and in its use, added to the complexity of the ISI's work by the middle of the twentieth century. Statistics to the nineteenth-century founders were numbers - data about populations, economic conditions, and diseases. Statisticians concerned themselves with collecting that data, with organizing them for presentation, and with drawing conclusions about the problems and conditions illuminated by the data. Those tasks still formed part of the work of the statistician in the middle of the twentieth century, but the process of collecting data and drawing conclusions had been dramatically transformed by the work on distribution theory, sampling, estimation, and hypothesis tests pioneered by Karl Pearson, R. A. Fisher, Jerzy Neyman, and Egon S. Pearson, to name only the most prominent of the earliest contributors.

Statisticians were no longer simply government officials who collected data. They were biologists who designed experiments on varieties of corn, industrial engineers who controlled the quality of mass-manufactured goods, social scientists who surveyed random samples of people in order to make inferences about larger populations, all kinds of scientists who needed probability-based models of the phenomena they studied, and mathematicians who created those models and studied their abstract properties. In addition to having a variety of research interests, many of these scientists unlike the government statisticians of previous decades - tended to depend on academic

\footnotetext{
${ }^{10}$ Cox puts the number of American (US) members at 20, with Cox as the only woman (Cox 1977, Caffrey Files), while Nixon puts the number of American members (representing an unspecified 5 countries) in 1948 at 38, though clearly "American" here refers to the broader continent rather than to the United States (Nixon 1960).
} 
institutions for employment, and on professional scientific societies for the dissemination of their ideas. The ISI served a much more diverse constituency in 1948 than it had in 1885.

The second major change to the landscape diversified the ISI's work in a different way. The end of World War II saw the creation of the United Nations, and with it more explicit efforts to promote international cooperation in a range of areas, as well as more funding to support those efforts. The main tasks of the ISI - coordinating the collection of demographic and economic data among various nations - became the domain of the United Nations Statistical Commission. ${ }^{11}$ Stuart Rice, president of the ISI from 1947 to 1953, had played an important role in the creation of the Commission, and is also usually credited with revising the ISI's statutes at this time, in order to carve out a new niche for the organization.

The changes to the statutes included both a shift in emphasis as well as the addition of new purposes. The ISI's statutes before 1948 stated the organization's goals as "promoting the progress of administrative and scientific statistics" (International Statistical Institute 1933). In particular, its purposes included recommending methods of collecting and displaying statistics that would make them comparable across national boundaries; making governments aware of the questions that could be resolved by the collection of statistics; producing publications that would promote relationships among statisticians from different countries; and promoting an interest in statistics among government officials and scholars (ibid.). The purposes listed in the statutes approved in 1948 still included "furthering international comparability of statistical data" (Rice 1947, 160). In these new statutes, however, the interest in facilitating international exchange went beyond this technical issue of comparing data to include a greater emphasis on the sharing of ideas among scientists. The ISI would now encourage "the international association of statisticians, the exchange among them of professional knowledge," and "the establishment of such relations among statistical societies ... as will further the international integration of statistics" (ibid.).

Even more novel was an emphasis on the advancement of knowledge in statistics and a recognition of the diversity in that knowledge. The Institute was now, for example, devoted to "studying statistical theories, appraising statistical methods and practices, encouraging statistical research, and furthering the use of statistical methods in diverse subject-matter fields wherever useful" (ibid.). Together, these new emphases - on bringing together statisticians from different statistical societies and on encouraging statistical research - reflected the increased importance of the professional work of academic statisticians.

There is some evidence to suggest that Cox had a hand in encouraging the ISI to move in this new direction. In August 1946, the University of North Carolina's Institute

\footnotetext{
${ }^{11}$ For a brief discussion of how one statistician who was connected with the UN perceived the differences between that agency and the League of Nations relative to collection and use of statistical information, see Latham 1946, 283.
} 
of Statistics (which Cox directed) hosted a small statistics conference in the mountains of North Carolina. Sixteen prominent statisticians participating in the conference, including Cox, signed a resolution noting that the ISI's traditional responsibilities were soon to "be assumed by the Statistical Commission of the Economic and Social Council of the United Nations," and urging the ISI "to extend its activities in other fields." The resolution especially highlighted "the profitable extension of statistical methods to new applications" in such fields as public health, the measurement of public opinion, and plant and animal husbandry (Cox et al. 1946, in Cox Papers). ${ }^{12}$ Several days after the resolution was signed, British statistician, Ronald A. Fisher, who had attended the conference, wrote to Cox that he had delivered the resolution to Stuart Rice. According to Fisher, Rice "expressed himself in cordial agreement with the resolution and declared it to be most encouraging." Fisher went on to suggest that the statistical work in which Rice took primary interest overlapped considerably with the work of the newly established Statistical Commission of the UN. "He has not," believed Fisher, "thought seriously of the change in character of the International Institute [ISI] which naturally follows on the establishment of the United Nations Organization. I should say, however, that although your attitude is new to him, he would not be antipathetic towards it" (Fisher to Cox, 12 August 1946, in Cox Papers). Whatever part Cox and her colleagues played in Rice's subsequent work to reconfigure the ISI's work and its relationship to the UN over the next decade, Cox became an active participant in the Institute, helping to coordinate its work and pursuing funding for its activities. ${ }^{13}$

Two other additions to the ISI's list of purposes also reflected the academic side of the statistics profession in the mid-twentieth century landscape. Moreover, they gave the ISI a role that removed it from competition with the purposes of the United Nations. The ISI carved out a new niche for itself in proposing to establish and maintain "professorships, lectureships, and fellowships for advanced studies in statistics," and to promote "the training of competent statisticians" (Rice 1947, 160).

Along with leading the effort to revise the ISI statutes, Stuart Rice forged an agreement with the United Nations whereby the two agencies would cooperate in efforts to improve the supply of statisticians. As a report on this agreement to the ISI explained, the UN would contribute the funds, and the ISI would supply education and training through its Education Committee. Of particular interest to Rice, and therefore to the ISI, was the improvement of statistical training in "under-developed areas." As he explained in the report, this interest emerged from a similar concern in the UN, which "is pledged in numerous ways to support a more rapid development

\footnotetext{
12 The other signatories of the resolution were Horace W. Norton, Gerhard Tintner, Carl F. Kossack, Chester I. Bliss, Churchill Eisenhart, William G. Cochran, Charles P. Winsor, Samuel S. Wilks, Frederick Mosteller, Frederick F. Stephan, John W. Tukey, Jacob Wolfowitz, Paul Peach, Charles F. Roos, and Walter A. Shewhart. Some anecdotes about the conference can be found in Anscombe 1988.

13 The minutes of the Education Committee's meetings list Cox as attending as early as 1957 (see International Statistical Institute 1957, ISI Archives).
} 
of under-developed areas" (International Statistical Institute 1949, 8).${ }^{14}$ According to Rice's logic, economic development required accurate statistical information, which in turn depended on the presence of well-trained statisticians in the countries needing assistance (ibid., 10).

The ISI's interest went beyond obtaining better information for economic development, however, and aimed ambitiously at raising the level of scientific practice. "The ultimate culmination of this purpose [was to] be the appearance in these areas of statisticians whose abilities, professional qualifications and scientific and administrative contributions [would] be on a parity with those of statisticians in any other part of the world" (ibid.). By tying its goals to the broader economic development work of the newly formed United Nations, the ISI had justification - and funding - for a project that had the potential to advance the discipline of statistics, to expand the geographical scope of its practice, and to create opportunities for international exchange among statisticians. Because the work of statisticians had, as described above, diversified extensively in the past fifty years, improving the supply of statisticians in developing countries meant, at least to ISI leaders, raising the level of science there as well.

Thus by the middle of the twentieth century, some statisticians had organized themselves into an international network of government and academic professionals with at least three specific purposes. They wanted to coordinate national census-taking, advance statistical scholarship as both a national and transnational activity, and promote the economic advancement of developing countries. To fulfill these purposes, more statisticians were needed, and the ISI formed its Education Committee to meet that need. In the early 1950s, as a result of the collaboration between the ISI and the UN, the ISI Education Committee helped establish and support statistics training centers in India and Lebanon. These centers provided training to government workers in collecting and analyzing data and received financial support from the United Nations Educational, Scientific and Cultural Organization (UNESCO), the governments of India and Lebanon, and the Ford Foundation (Gani 1979, 238; Goudswaard 1964, 92). After setting up these training centers, the Education Committee decided "to explore the needs and possibilities for a regional statistical education centre in tropical Africa" (International Statistical Institute 1958, ISI Archives).

This move came in response to a suggestion from the committee's UNESCO representative, B. A. Liu, who reported at the 1958 committee meeting that the UN Economic Commission for Africa had recently been established. The Education Committee's exploration went slowly, and two years later, frustrated with this slow pace, Liu wrote to Cox in December, 1960, of UNESCO's plans to include statistics training for African civil servants in its upcoming annual budget. "You know I have tried to get the ISI Education Committee to take a special interest in promoting statistical

\footnotetext{
${ }^{14}$ No author of this paper is specified, but G. Goudswaard, who was director of the ISI's Permanent Office at the time, writes that it was "in large part written by Dr. Rice" (see Goudswaard 1964, 89).
} 
education in Africa," he reminded her, "but events are moving faster in Africa than the ISI Committee can keep abreast of' (Liu to Cox, 28 December 1960, in Cox Papers). Liu, who had known Cox at least since 1955, had written to her because of his "great respect for [her] broad perspectives and sound judgment," hoping that some definite plan would emerge from the next committee meeting, to be held in Paris in August 1961 (ibid.). ${ }^{15}$

Cox shared Liu's frustration, and by the time she became the Committee's chairman, she was steering it toward work in Africa. At the Paris meeting, the committee had discussed the potential to create a training center at the newly established University of East Africa (consisting of Makerere College in Uganda, Royal College of Nairobi, and University College, Tanganyika) or at the University College of Rhodesia and Nyasaland. ${ }^{16}$ Cox also thought that "there should be some way to use the facilities and personnel at the three universities in the Union of South Africa" (Cox to H. L. Manning, 10 January 1962, in Cox Papers).

In the latter case, she expressed some concerns about racial issues and whether these institutions admitted African students along with Europeans. In a letter to a former student, H. L. Manning, who was then doing agricultural research in Uganda, she confessed, "I should understand more about the race problems in Africa." She also worried about a narrowness of focus in the proposal from Makerere College. "As you know," she wrote to Manning, "I would strongly urge a well-rounded program including basic methods and theory. The statistics needed in economics and for official statistics should be a part of the statistics degree program, but no greater a part than experimental designs and analysis of variance tools" (ibid.).

In a letter to Bart Lunenberg, director of the ISI's permanent office in The Hague, she raised similar issues about the proposal from the University College of Rhodesia and Nyasaland. "I believe there is some question yet about whether their University is really interested in the education of Africans," she told Lunenberg. Moreover, she thought that the proposal, like that for Makerere College, put too much emphasis on economics training and the collection of official statistics. As she put it, "especially in Africa one must plan not only for better official statistics but for better experimental work in agriculture, medicine and industry" (Cox to Lunenberg, 8 January 1962, in Cox Papers).

Both the concerns about narrowness of curriculum and the racial issues highlight complications created by the move toward independence in these countries during the 1960s. They suggest that investigations of the impact of colonialism on education would provide important perspectives for the study of the internationalization of statistics in

\footnotetext{
${ }^{15}$ Cox and Liu both appear on the list of people present at the 1955 ISI Education Committee meeting (see International Statistical Institute 1955, ISI Archives).

16 Tanganyika is now known as Tanzania. The Federation of Rhodesia and Nyasaland, in existence from 19531963, was comprised of the former British protectorates of Northern Rhodesia, Southern Rhodesia, and Nyasaland, which eventually became Zambia, Zimbabwe, and Malawi, respectively.
} 
this period (see Lulat 2005). The institutions Cox was investigating were either newly created or in the process of establishing their autonomy from parent institutions in England. The existing curricula were based on a system that gave degree-granting authority to the parent institutions. Cox's concerns about the scope and focus of university statistics programs in Africa also reflected the changes that had occurred to the profession's landscape over the previous half century. An emphasis on economic and official statistics was narrow and outdated by this time, while statistical experiments and probability-based methods of analyzing data had become commonplace in scientific research in the United States and other developed countries.

The promotion in African institutions of these newer aspects of the discipline would not only meet needs but ought to attract funding. "I think some of the agricultural and industrial interests in Rhodesia would help finance a program in statistics training" (Cox to Lunenberg, 8 January 1962, in Cox Papers). Cox also looked to UNESCO and US philanthropies as sources of funding. She intended to pursue these sources, assuring Lunenberg that "As soon as possible, I will visit the Foundation folks in New York for exploratory purposes" (ibid.).

\section{The Ford Foundation, Overseas Development, and University Statistics Training}

In particular, Cox had plans to meet with officials from the Ford Foundation. Founded in 1936 by Henry Ford and his son Edsel, the Ford Foundation began as a family philanthropy, making grants in the Fords' home state of Michigan. After the deaths of Edsel Ford in 1943 and Henry Ford in 1947, the Foundation reorganized as a national philanthropy, independent of Ford family control. At the same time, it broadened the scope of its grant-making.

The report of a specially appointed committee of outside consultants, headed by $\mathrm{H}$. Rowan Gaither, Jr., provided the framework for that broadening of activity. Gaither's committee particularly emphasized the role the Foundation should play in working to prevent war and to promote peace. Along with encouraging immediate efforts "to strengthen the structure of international organization" and "to support endeavors which will have an impact on national or United Nations policies or procedures" (Gaither et al. 1949, 54), the report urged the Foundation to begin making "plans for aid to underdeveloped areas of the world" (ibid.). ${ }^{17}$ Such aid would help alleviate conditions conducive to conflict, particularly among countries threatened by "the tide of communism" mounting in Asia and Europe (ibid., 26). Admitting that " $\mathrm{t}]$ he needs of such peoples particularly in underdeveloped areas, are vast and seemingly endless,"

17 "The Establishment of Peace" was only one of five program areas mapped out by Gaither's report. The others focused on domestic issues: "the strengthening of democracy, the strengthening of the economy, the improvement of education, and the better understanding of man" (Gaither et al. 1949, 14-15). 
the report asserted that "their eventual well-being may prove essential to our own security" (ibid., 26-27). Without making specific suggestions regarding projects to fund, the committee emphasized the urgent need in underdeveloped countries for "knowledge, guidance, and capital," resources that the United States seemed uniquely positioned to provide (ibid., 27).

Even on the surface, the language used and the issues raised in Gaither's report relative to world peace and assistance to developing countries resembles the "Point IV" program initiated by President Truman in his 1949 inaugural address. ${ }^{18}$ The role and administration of technical assistance to developing countries in American foreign policy took several forms from its inception in the Point IV program through the late 1960s. A variety of views about political development motivated the programs, from a belief that the economic growth resulting from technical assistance would promote political development and possibly strengthen liberal democracy, to the assumption that technical aid could contribute to US security by blocking Communist expansion in developing countries. ${ }^{19}$

These different views find expression in Ford Foundation documents from this period as well. Describing the first grants through the Overseas Development Program, created in response to the Gaither report, the Foundation's 1951 Annual Report made specific reference to projects connected to Point IV (Ford Foundation 1951, 12). That year, Ford had appropriated $\$ 6,550,000$ for grants to India, Pakistan, and the Middle East. With this money, the Foundation hoped to "help the people help themselves toward a better standard of living, in which are included better means of education and better organization of social life" (ibid., 10). As a 1952 policy document explained, Ford chose these regions because of the "many newly emergent nations precariously situated along the periphery of the Soviet-Communist orbit."20

That Ford's rationale for its overseas development programs echoed government policy is not surprising, for as Edward H. Berman documents in The Ideology of Philanthropy, several Ford administrators in the 1950s and 1960s had close ties to the United States foreign-policy establishment. Before becoming the Foundation's president in 1950, Paul Hoffman had been director of the Economic Cooperation Administration, the agency administering Truman's Marshall Plan for recovery aid to Europe after World War II. John J. McCloy, who served as chairman of Ford's board of trustees from 1958 to 1965, had been Assistant Secretary of War and first high commissioner to Germany after World War II. McGeorge Bundy was National Security Advisor to Presidents Kennedy and Johnson before becoming president of the

\footnotetext{
18 The name "Point IV" came from the fact that the program was described in the fourth of Truman's points on foreign policy objectives.

${ }^{19}$ For a discussion of the changing role of technical assistance in American foreign policy from 1947 to 1968 , see Packenham 1973.

${ }^{20}$ Carl Spaeth, "Program for Asia and the Near East," Ford Foundation International Training and Research Papers, Administration, Board of Overseas Training and Research, 1952, p. 1, as quoted by Berman $1983,56$.
} 
Foundation in 1966 (Berman 1983, 63). As Berman points out, the rationale given by the Ford Foundation for its overseas programs during the Cold War period "was remarkably similar to that issuing from the departments of State and Defense ... as justification for a more active American involvement abroad" (ibid., 42).

By 1962, when Cox approached the Foundation about supporting statistics training in Africa, Ford had spent $\$ 152.6$ million in forty countries in Asia, Africa, the Near East, Latin America, and the Caribbean. Describing this grant making, a 1962 Ford report categorized the assistance as "largely in support of education, training, and research institutions and activities essential to the recipient countries' own programs of social, economic, and educational advancement" (Board of Trustees 1962, 8). As it looked to the decade ahead, this 1962 report promised that the Foundation would "continue to assist efforts of these countries to establish or improve their educational institutions, programs, and practices as a means of producing the trained leaders, skilled persons, and enlightened citizens essential to their national development" (ibid., 12). The Foundation also planned to contribute to rural development overseas, giving support "to institutions and programs to increase agricultural production, improve rural life, and raise nutritional levels" (ibid., 13). Cox had long believed that statistical methods could play an important role in such work and her efforts on behalf of statistics programs in Africa simply continued a pattern of advocacy established early in her career.

On January 17, 1962, fulfilling her promise to Lunenberg to "visit the Foundation folks," Cox had what she described as a "most profitable session" with F. Champion Ward, head of the Ford Foundation's Near East and Africa Program. As she wrote to William Leonard, a statistician working in the UN's Economic Commission for Africa, she had briefed Ward on UNESCO and ISI interest in promoting statistics training in Africa. ${ }^{21}$ Ward indicated that the Foundation was considering supporting the overall development of the University of East Africa. "It became increasingly evident," she told Leonard, "that our chances of getting funds for statistical training at the University of East Africa were quite good" (Cox to Leonard, 29 January 1962, in Cox Papers).

To some extent, Cox's confidence derived from an ability to read between the lines. As she would later tell a correspondent, foundation officials tended to talk "in general terms for they are skillful at making no commitments" (Cox to C. P. Welter, 9 July 1963, in Cox Papers). In the meeting, she and Ward discussed the University of East Africa, as well as the proposal and possible budget for the University College of Rhodesia and Nyasaland. In the course of the conversation, Cox "realized that Dr. Ward had reservations" about the latter institution. While "it was difficult to get much response of a constructive nature," Ward finally expressed his doubts about whether Africans would choose to attend the university. Then, just as the meeting ended, Ward mentioned the University College of Ibadan in Nigeria, going on "enthusiastically

${ }^{21}$ On Leonard, see Ryan 1982. 
about the College," its medical school, and its research in agriculture and economics. Apparently, "he felt that the political and racial problems would be less there than at most any other place in Africa." As Cox reported to Leonard, "This came as a surprise move to me. Dr. Ward had given me almost two hours of his time and it was near closing time." She told Ward that she would investigate the Nigerian college's potential for providing statistics training (Cox to Leonard, 29 January 1962, in Cox Papers). ${ }^{22}$

Cox continued to make inquiries into possibilities for statistics training in Africa through the first seven months of 1962, establishing contacts among university professors and administrators, government officials, and people connected with United Nations and United States agencies. In August, she spent a week in the region to get a first-hand sense of the possibilities for establishing training programs. Spending two days in Salisbury, she provided some advice on the University College of Rhodesia and Nyasaland's proposal for an Institute of Statistics. The university submitted this proposal in November, 1962, to the Ford Foundation, which turned it down (Cox 1963, in Cox Papers). ${ }^{23}$

Cox also met with officials at the University of East Africa to discuss their aspirations for improving statistics education. No immediate action resulted from these discussions, but at its August 1962 meeting at the end of Cox's trip, the ISI Education Committee recommended that the ISI "help establish a stronger program" at the University of East Africa and that Cox and B. A. Liu prepare a program plan (ibid.). Preparing such a plan turned out to be difficult, primarily because the key statisticians at the institutions involved had conflicting priorities. Moreover, subsequent meetings with Ford Foundation officials "led [Cox] to believe that they were really interested, but [that] they felt that the University of East Africa and the political situation in that area had to become clearer before much could be done" (Cox to Mr. and Mrs. D. C. Upton, 24 June 1963, in Cox Papers). ${ }^{24}$

This brief account of the Ford Foundation helps explain why it eventually supported university statistics in Egypt. More broadly, the account contributes to this case study by uncovering some features of Cold War science patronage that need further exploration.

\footnotetext{
${ }^{22}$ Cox's work with the ISI Education Committee did not ultimately lead to any connections with the Nigerian institution.

${ }^{23}$ Cox presented this report of her work on establishing statistical education centers in Africa to the ISI Education Committee at its 1963 meeting in Ottawa. She must have learned of the Ford Foundation rejection of the University College proposal just before the meeting, as her handwritten notation "Turned down" appears in the margin by the typed statement, "I have no report on the status of this proposal." Since the Federation of Rhodesia and Nyasaland broke up in December 1963 and the territories of Northern Rhodesia and Nyasaland became the independent nations of Zambia and Malawi the following year, it seems likely that the uncertain political situation in the region played a role in the Ford Foundation's rejection of the grant proposal.

${ }^{24}$ Cox had met with Upton, who worked in the Tanganyika Treasury Department, during her trip to Africa. Cox does not seem to have taken an active part in further efforts to promote statistics training in these countries. Makerere University established an Institute of Statistics and Applied Economics in 1969; Ibadan University began awarding professional diplomas in statistics in 1965 through its departments of mathematics and economics; and the University of Dar-es-Salaam, Tanzania formed a department of statistics in 1967 (see Ntozi 1992, 468).
} 
In particular, we see that Ford's technical assistance agenda had close ties to American foreign policy, and particularly to efforts to keep newly-independent countries from turning to the Soviet Union for support. Aid to universities played at least some role in Ford's strategy for achieving its agenda, and university teaching and research in statistics benefited from that aid, in part because Cox and others persuaded Ford officials that academically trained statisticians could contribute to a country's economic and social development.

This account also reveals signs of tension among the agendas of the participants in the negotiations for aid. Ford wanted to fend off communism by promoting economic development and Cox and some of her colleagues in the ISI saw experimental statistics as a tool for that development. Some university statisticians wanted to emphasize economics and official statistics, in part out of an interest in national economic development, but also, possibly, because they saw that path as the way toward more academic prestige in the international arena. For the same reason, the Egyptians at the ISSR, as the account below will indicate, seemed more interested in the mathematical aspects of statistics research.

With the data available for this case study, these claims about conflicting agendas and the convergence of university statistics (along with other sciences), Foundation technical assistance to developing countries, and US foreign policy concerns in the Cold War can be made only tentatively. Ford's assistance to the ISSR in Egypt is just one example of this convergence. The archives of the Ford Foundation contain files on similar projects dating from the 1950s through the 1970s in India, Thailand, Indonesia, Turkey, Mexico, and Brazil. Further research into these projects, framed in part by the issues raised in this study of Cox's work in Egypt, would allow a more complete picture to emerge.

\section{The Journey to Egypt and Cox's Work for the ISSR}

From the beginning of her work as chairman of the Education Committee, Cox had been talking with Ford representatives about funding statistics training in developing countries. From January 1962 through August 1963, she focused primarily on needs in eastern Africa. Meanwhile, the Foundation representative in Cairo, John Hilliard, was preparing a proposal to fund a statistics program in Egypt. A week after Cox first met with Champion Ward in January 1962, Hilliard wrote to Ward that he had been "approached by Dr. Hassan Hussein, Under Secretary of State for Statistics ... regarding Foundation support for establishment of a National Institute of Statistics." Hilliard explained that "Hussein is looked upon as the legitimate dean" of the group of "a few highly qualified people in the various statistical specializations in Egypt." In the last few years, accurate statistical information had become "a critical factor in national planning and in monitoring the execution of the plan for national development," and Hilliard described an emerging "recognition of the need for a competent central 
statistical agency" that could coordinate the country's statistical training and research (Hilliard to Ward, 25 January 1962, Ford Archives, Grant \#63-501).

Within two months of Cox's meeting with Ward and Hilliard's letter to him, another Ford staff member in the Near East and Africa division, David MacEachron, was thanking Cox for her "generous offer to help find suitable candidates for the assignment in the U.A.R. [Egypt]" (MacEachron to Cox, 22 March 1962, in Cox Papers). ${ }^{25}$ Plans were underway for the Foundation to send what it called "program specialists," or visiting consultants, to the Egyptian statistics training center, "when it is formally established," and to provide fellowships for Egyptian students to study abroad. MacEachron hoped that Cox could suggest names of statisticians who would serve as consultants.

He acknowledged that Cox knew "the situation in Cairo so much more thoroughly than I" (ibid.), and indeed, as Cox replied in her letter, "Before and since my visit to Egypt in 1953, we have been intimately associated with the training of Egyptian statisticians." The University of North Carolina had trained "quite a few" Egyptian students who now worked in government, universities, and research programs in Egypt. Cox was acquainted with Husein and Abdul Moneim El Shafei, another Egyptian official with whom the Ford Foundation was negotiating its grant (ibid.). ${ }^{26}$ In fact, Cox had given Shafei some advice about getting funding for a graduate program in statistics at Cairo University after a 1955 ISI Education Committee meeting. At that meeting, participants had discussed the possibility of establishing a training center in Egypt similar to the ones in India and Beirut. The programs there served students from several countries in the regions surrounding India and Lebanon, and the committee had decided against working with Cairo University because of its plans "for a centre with a more national character." Apparently, "it would not be in line with the general policy of the International Statistical Institute to co-sponsor a national centre" (International Statistical Institute 1957, 231). Perceiving that the statistics program at Cairo University lacked a sufficiently regional scope, the ISI would not contribute funds for the program's development. The Education Committee's initial interest in

\footnotetext{
25 This letter is also in Grant \# 63-501, Ford Archives. Neither archive collection contains documents explaining when Cox offered to help with this project. It is possible that she discussed the issue with Ward at their January meeting, or that the offer emerged in subsequent phone conversations. She had certainly made a favorable impression at her meeting with Ward. As MacEachron reported to Hilliard, "Champ is very impressed with Dr. Cox and thinks that she has about as thorough a knowledge in the statistical field as anybody around" (MacEachron to Hilliard, 6 April 1962, Ford Archives, Grant \# 63-501). Note that Syria and Egypt united in 1958 to form the United Arab Republic (UAR). Syria seceded from the union in 1961, but Egypt continued to be known as the UAR until 1971.

${ }^{26}$ As part of a trip to attend the 1953 ISI meetings in Italy, Cox had visited Lebanon, Egypt, South Africa, Uganda, and Rhodesia (Cox n.d., Caffrey Files). On this tour, she visited at least one former student, H. L. Manning, the first degree recipient of North Carolina State's Institute of Statistics (see Cox to Lunenberg, 8 January 1962, in Cox Papers). Both Shafei and Husein received their Ph.D.s in England (see Sarhan 1957, 15; Annals of Mathematical Statistics 1953, 317). In his own letters, Hasan Husein spelled his names with a single "s."
} 
supporting the development of programs having a regional and not merely national impact hints at a commitment to an explicit internationalism, echoing the language of the revised 1948 ISI statutes, discussed above, that called for furthering "the international integration of statistics" (Rice 1947, 160). Cox, however, who attended the 1955 committee meeting, "contacted Dr. Shafei concerning the ISI discussion and provided suggestions of possible financial help for consideration by the authorities in Egypt" (Sarhan 1957, 16). ${ }^{27}$

At its 1961 Paris meeting - the same meeting that initiated Cox's work in Africa the ISI Education Committee had helped draft a curriculum "for an M.S. in statistics [at Cairo University] which would prepare the better students who desired advanced training to enter Ph.D. programs in statistics in the United States." As she put it in her letter to MacEachron, "We are exceedingly interested in doing all we can to help them with the development of the National Institute of Statistics" (Cox to MacEachron, 2 April 1962, in Cox Papers).

The Ford Foundation's interest in the program persisted, and in January 1963, Hilliard sent a proposal for funding to Ward. Hilliard's proposal eventually became a "Request for Grant Action" (RGA), submitted to Ford's president in July 1963. It provides a sense of what the Foundation hoped to accomplish with its support of the ISSR, and how that support fit into broader Foundation goals. The RGA noted that since announcing an industrial development plan in 1957, the government of Egypt had "recognized a weakness in its ability to provide the statistical information required" for implementing it. The grant to the ISSR would help solve this problem by improving training for "statisticians qualified to serve the industries, ministries, and agencies responsible for the execution of the current development plan" (Request for Grant Action, 31 July 1963, Ford Archives, Grant \#63-501). This rationale clearly echoed Ford's 1962 description of its future agenda, discussed above, that described its plans to train leaders in the less-developed countries who would contribute to national economic development. ${ }^{28}$

\footnotetext{
${ }^{27}$ After receiving the Ford Foundation's request for advice in 1962 concerning the Cairo program, Cox wrote to Shafei for more information, congratulating him on the recent developments. Noting that she had become chairman of the Education Committee, she acknowledged, "You are making progress without ISI. I've been bitter about the way Mahalanobis treated you folks" (Cox to Shafei, 2 April 1962, in Cox Papers). Prasanta Chandra Mahalanobis, an Indian statistician, had been chairman of the Education Committee in 1955. Cox's assistance to Shafei after the 1955 meeting and her remark to him in 1962 suggest that she disapproved of the committee's unwillingness to help Cairo University, though no explicit evidence of this disapproval has come to light.

${ }^{28}$ Ford Foundation support for statistics training in other developing countries during this time emerged from similar motives. For example, Ford made a grant to the Indian Statistical Institute in 1958, and one in 1964 to establish a Department of Statistics at Padjadjaran University in Indonesia, in each case pointing out the importance of accurate data on population and agricultural production for the country's economic development. On India, see ("Request for Allocation and Grant Action," 14 May 1958, Ford Archives, Grant \# 58-217); on Indonesia, ("Request for Grant Action,” 16 September 1964, Ford Archives, Grant \# 650-0009).
} 
Significant Foundation involvement in Egypt had begun in 1959, when John Hilliard became the Foundation's first representative in the country, and the government received about $\$ 300,000$ in grants to train senior managers and economists. This government was led by Gamal Abdel Nasser, who had become president of Egypt in 1954, after leading the 1952 revolution that overthrew King Farouk. A detailed description of the complexities of US-Egyptian relations during this period is beyond the scope of this study, but if, as the evidence discussed above suggests, one of Ford's purposes in making grants to developing countries was to strengthen nations at risk of Soviet influence, the political events in Egypt in the 1950s and early 1960s made that country a natural choice for foundation involvement. Nasser's nationalizing of the Suez Canal, the aid he received from the Soviet Union for the Aswan High Dam, and his leadership in the Non-Aligned movement kept US foreign policy directors struggling to define a position that would protect American interests in the region (Hahn 1991). Ford's contributions toward Egyptian development in general and the ISSR in particular were consistent with those efforts.

In the early stages of preparation of the ISSR grant, Ford officials turned to Cox for some of the advice and consulting the ISSR needed to get established. Cox began a search for a visiting statistician to advise the ISSR, simply extending her recruiting work for the ISI Education Committee as she assisted the Ford Foundation on an informal basis. In September 1963, the Foundation formalized her advising role with a contract that would pay her for the recruiting work (Harvey Hall to Cox, 20 September 1963, in Cox Papers). ${ }^{29}$ Cox described this appointment to a colleague at the Research Triangle Institute as giving "status to the work I have been doing as part of my professional responsibility for the Education Committee of the International Statistical Institute" (Cox to George Herbert, 3 October 1963, in Cox Papers).

The people she suggested had a range of experience and prestige. Some were recent graduates of the programs in North Carolina; some served on the faculty in those programs. One recent graduate, William Mallios, had completed a Ph.D. in experimental statistics at NC State in 1962 and had been working for a management consulting firm (Mallios to Harvey Hall, 29 May 1963, Ford Archives, Grant \#639504). Cox urged Husein to consider hiring Mallios, believing that he had "the capabilities necessary to direct masters thesis work," and the ability to provide consulting services for researchers in other fields, though she admitted that "his name does not carry the prestige value" that Husein wanted (Cox to Husein, 3 October 1963, in Cox Papers). She proposed that Mallios begin immediately, while they continued to recruit a more senior statistician.

In his reply, Husein indicated that he wanted to hold out for a more experienced program specialist. Taking a point of view that Cox would later criticize as a hindrance to the ISSR's development, he downplayed the importance of bringing in someone

\footnotetext{
29 The contract provided for a fee of $\$ 90$ per day, any required air travel, and reimbursement of expenses. It covered 30 days of work over a period of one year (Robert Schmid to Cox, 30 September 1963, in Cox Papers).
} 
with consulting abilities and expressed more interest in having someone "with a strong theoretical backgrou[n]d who can handle some masters and doctors [sic] degree theses.... Consul[t]ation is also useful but can perhaps come later on. The main thing for him is to be able to do research with graduates" (Husein to Cox, 19 September 1963, in Cox Papers). ${ }^{30}$

Cox continued recruiting statisticians for the next several months, and by December 31, 1963, Cox reported to Husein that she had tentative agreements from three statisticians to serve as visiting faculty at the ISSR in the coming years: Carl Marshall, Robert Hader, and Paul S. Anderson, Jr. ${ }^{31}$ Marshall, who would go to Cairo in 1965, helped create the statistics program at Oklahoma State University and had a Ph.D. from Iowa State University. ${ }^{32}$ Hader, tentatively available in 1966 or 1967, had received a Ph.D. from NC State's Department of Experimental Statistics in 1949, and subsequently joined its faculty. Paul Anderson taught in the Department of Epidemiology and Public Health at Yale and was interested in going to Cairo in 1968.

The ISSR and Ford had hoped to hire a program specialist for the 1964-65 academic year and Cox told Husein in her December letter that she planned to meet with Harvey Hall at the Foundation on January 10. "If he agrees with my suggestion," she wrote, "we will propose to you the name of a person for the Fall of 1964" (Cox to Husein, 31 December 1963, in Cox Papers). The proposal met with approval. The ISSR would have its mature, experienced statistician with prestige value. As Lipscomb wrote to a colleague at the Foundation in February, "Dr. Hussein was delighted to have word that Dr. Cox might be available to come and work with ISSR ... during the 196465 academic year" (Lipscomb to Donald Kingsley, 13 February 1964, Ford Archives, Grant \#639-504). 33

Cox landed in Cairo on the fifth of September with little more than a vague sense of the Institute's expectations of her and of the role she could play in furthering the goals of its staff. By the end of October, when she sent out her first "Diary Letter" from Egypt to friends and colleagues in the States, Cox had established something of a routine. She was teaching a weekly class for research workers and a graduate course of nine students twice a week, with plans being made for an elementary course for diploma students. Her busy consulting schedule included agricultural studies, research on infant mortality and family planning, and work for the university's School of Pharmacology (Cox, Diary Letter No. 3, 30 October 1964, in Cox Papers).

When possible, she had her graduate students participate in the analysis of the data obtained in her consulting work (ibid.). She found them lacking experience with

\footnotetext{
${ }^{30}$ Clearly, Husein is responding in this letter to Cox's letter of 3 October, so it seems that the date on the letter must be incorrect.

${ }^{31}$ Ultimately, Hader and Anderson did not go to Cairo.

${ }^{32}$ Marshall had been at Oklahoma State University since 1931. He earned his Ph.D. in 1956. His other experience abroad included work for the US State Department in 1947, overseeing the Greek election, and statistical consulting for a Point IV program in Ethiopia in 1953 (Marshall 1992, in Cleveland Files).

${ }^{33}$ Kingsley was director of Ford's Middle East and Africa office in 1964.
} 
the applications of the statistical methods they had learned: "They know about the statistical tools but they do not know much about when and how to use them." Asssessing the local faculty, she observed that "the teachers of statistics have done no research or consulting work except maybe in economics," so that their attempts to analyze research data were often done "text book style" (Cox to C. and E. Cox, 2 November 1964, Caffrey Files).

By the spring, Cox was still "doing a great deal of consulting," along with supervising the research of five graduate students at the Institute and teaching four classes, including a weekly course at the university in Alexandria, a two-hour train ride from Cairo (Cox to C. and E. Cox, 29 May 1965, in Caffrey Files). Outside her course work, she gave lectures on the need for statistical methods in research to others in the university and traveled to Beirut to visit the ISI's International Statistical Education Center, giving several lectures there (Cox 1953, 1965a, 1965b, in Cox Papers).

As her time in Egypt approached its end, Cox puzzled over how organizations such as the ISI and the Ford Foundation could continue promoting statistics education in Egypt and in other developing countries. Eight months into her work at the ISSR, she wrote to the director of the ISI, Bart Lunenberg, that her "experiences ... here have been a real education to me regarding how the education in stat[istics] should be developed in these countries." Still, she admitted, "I am more confused than ever to know how we can assist these developing countries with their statistical education problems" (Cox to Lunenberg, 19 April 1964, in Cox Papers).

While she may have been confused about the most effective way to assist statisticians in Egypt and elsewhere, Cox had definite ideas about what their programs needed. She spelled out these ideas in her report to the ISSR and the Ford Foundation at the conclusion of her stay. First, she asserted that the effective training of Egyptian statisticians would continue to require input from statisticians abroad. "It seems desirable," she wrote in her report, "to keep on the ISSR program one or two visiting statisticians who have had extensive experience consulting, directing research, supervising theses and teaching" (Cox 1965c, in Cox Papers).

In addition to suggesting that the ISSR bring in visiting statisticians, Cox noted that for at least several more years, Egyptian students would need to go abroad themselves for advanced training. She had recommended to Hasan Husein, the director of the ISSR, that her five graduate students from the Institute be sent to the United States to complete Ph.D.s in statistics. Shortly before her departure from Cairo, Cox noted in a letter to her brother that "two of this group will be in Chapel Hill [UNC] this Fall" (Cox to C. and E. Cox, 2 July 1965, Caffrey Files).

Cox was particularly concerned that the education of Egyptian students in statistics, whether at home or abroad, include "more instruction and experience in the use of statistical techniques." Statisticians teaching graduate students at the ISSR must, she insisted, "be research oriented and preferably should be actively engaged in research" (Cox 1965c, in Cox Papers). Research, as Cox used the term here, meant the use of statistical methods to investigate agricultural, social, or economic problems, rather 
than the creation of new methods or the advancement of knowledge in statistical theory.

Cox had in mind the sort of research she had done in her consulting work at the ISSR. The importance of consulting, she observed, had not received enough attention from Egyptian statisticians. In a memorandum to the Ford Foundation accompanying her report on the Institute, she noted that "the need for consultant help in statistics by research workers is much greater and more urgent than is realized by the present staff of the Institute" (Cox to Ford Foundation Staff, 11 August 1965, in Cox Papers). She pointed out that many of these research workers had studied abroad "at universities where statistical courses were required and where consulting statisticians were available ... to assist them with their research" (Cox 1965c, in Cox Papers). Thus these scientists were prepared to make use of consulting services if the ISSR could provide them.

Statisticians at the ISSR had emphasized research in theoretical statistics, a phenomenon that perhaps had roots in the early history of university statistics training in Cairo. In her first discussions with the Ford Foundation about funding the ISSR, Cox told of an effort in the 1950s to coordinate statistics teaching in Cairo University's Faculty of Commerce and its Mathematics Department. The attempt led to the demise of the program, as "all the official and applied aspects were lost to pure mathematical statistics" (Cox to MacEachron, 2 April 1962, in Cox Papers). ${ }^{34}$ Cox also attributed some of the current neglect of consulting to its lack of prestige in Egypt. In her letter to Lunenberg, Cox explained that consulting at the ISSR did not "hold the same level of stature as does Math[ematical] Stat[istics]" (Cox to Lunenberg, 19 April 1965, in Cox Papers). Moreover, as she told the Ford Foundation, university administrators in Cairo did not tend to recognize consulting "as part of a University job," so professors at the ISSR had little incentive to take on such work (Cox to Ford Foundation Staff, 11 August 1965, in Cox Papers). ${ }^{35}$

The initial emphasis at the ISSR on statistical theory and the lower status of statistical consulting there reflect the diversity of the statistics profession in the mid-1960s and the complexity it brought to the promotion of university statistics programs, especially in countries trying to move toward the center of the scientific empire. They also echoed a debate among American statisticians that had begun in the 1920s, just as that diversity was becoming apparent to the range of researchers taking up work in statistics. Then, and for several more decades, those scientists in the US who would soon call themselves mathematical statisticians had been concerned that instruction in statistics did not include substantial enough emphasis on mathematics and statistical theory (Rietz and Crathorne 1926; Hotelling 1940).

\footnotetext{
${ }^{34}$ For an account of these efforts from a participant, see Sarhan 1957.

35 This neglect occurred in other university programs in developing countries. Writing about university courses in Iran, a government official there told Cox that "the emphasis is on theoretical aspects of statistical methods rather than on practical and operational aspects" (A. S. Shaheen to Cox, 19 December 1964, in Cox Papers).
} 
Indeed, the creation of the mathematical statistics community in the United States had resulted, in part, from statisticians' drawing a distinction between theory and application. In defining their discipline as its own field of study, American mathematical statisticians had argued repeatedly that the subject was more than simply a collection of tools used by researchers in economics, psychology, and agriculture. Theory and application of statistics were never completely separated, but different statisticians took different approaches to the delineation of the boundary between them, especially in the first decades of the American mathematical statistics community's existence (Hunter 1996).

For example, at Iowa State, discussed above, George Snedecor and his colleagues generated new ideas in the design and analysis of experiments and eventually sponsored research and taught courses, first in the Mathematical Statistical Service (which became the Statistical Laboratory) and later in a department of statistics. While statistics there did have the status of an independent discipline, it functioned in large measure in service to other sciences. In contrast, at Princeton University, statistics was taught in the mathematics department, and both the courses offered and the research of faculty there consequently emphasized statistical theory and probability. The Institute of Statistics, affiliated with both the University of North Carolina and NC State was unique in its deliberate efforts to balance theory and applications - or mathematical and experimental statistics. The departments at UNC and NC State emphasized different aspects of the discipline in their teaching and research, but both had equal status in the Institute of Statistics. Moreover, statisticians in both departments engaged in consulting work with other scientists and published papers in journals representing the range of sub-disciplines - both theoretical and applied - within the field of statistics. ${ }^{36}$

Cox's prestige in the statistics community derived from her contributions to teaching and using experimental statistics and from her role in establishing, promoting, and obtaining funding for university statistics programs - primarily but not exclusively programs that emphasized applied statistics. Her creation of the Department of Mathematical Statistics at UNC indicates that she supported and advanced the work of mathematical statistics. Nevertheless, she advised the ISSR to emphasize applications for the time being. In fact, she discouraged the Egyptians from pursuing theoretical studies in this early stage of their program's development. Again in her recommendations to the Institute and the Ford Foundation she wrote, "Very few of the staff members at the early stages of a developing program need to be actively doing research in statistical theory. ... they should be testing sampling techniques, making plans for experiments and providing methods of analysis" (Cox 1965c, in Cox Papers).

Because many statisticians in developing countries such as Egypt were educated in the United States, the tension there may have played a role in their attitudes toward theory and applications. They may have perceived that an emphasis on the mathematical

\footnotetext{
${ }^{36}$ For a discussion of the range of institutional approaches to including statistics in university curricula, see Hunter 1997.
} 
side of the discipline would raise the status of their programs. That emphasis would naturally create some conflict with donor agencies such as the Ford Foundation and the UN, for whom the promotion of economic development was the justification for aiding statistics education.

For historians who might see in this example of Cox's work with the Ford Foundation in Cairo evidence that such donor agencies and other supporters of statistical education in developing countries deliberately targeted programs in applied statistics for assistance, we should note that while Cox was very clear in her report about the value of applied over theoretical work, the record of Ford's initial interest in the ISSR does not give evidence that Foundation officials had a sense of this dichotomy as they made their grant decisions. Indeed, it seems unlikely that much awareness of the debate between mathematical and applied statisticians existed outside the statistics community itself. On the other hand, to the extent that statisticians in the United States took an active role in promoting the advancement of university statistics in developing countries, the example of Cox's work in Egypt does suggest that applied statisticians were more likely to participate than mathematical statisticians. To establish such a claim conclusively, however, would require an examination and analysis of more examples than this case study is meant to provide.

Cox's reports and letters make clear that she perceived a conflict between the ideas of the ISSR staff and her own sense of what the program there should emphasize. In fact, she continued to sound the call for statistics programs that emphasized practical experience for students long after she left Egypt, so this advice was not confined to the ISSR. Not enough evidence has come to light to confirm that the Egyptian statisticians themselves were aware of the conflict, or even that they consciously preferred to create a more mathematical program than Cox was recommending. ${ }^{37}$ Nevertheless, as the next section will show, the establishment of consulting services at the ISSR continued to make only slow progress in the years after Cox's visit.

\section{Subsequent Developments in Cairo}

Following Cox's year at the ISSR, the Ford Foundation sent twelve more program specialists to Cairo. Cox herself recruited the first two, Carl Marshall of Oklahoma State University, and Ralph Bradley, then at Florida State University. As late as May 1967, while Bradley was in Cairo, the Ford program officer for overseas development, Thomas Scott, was asking Cox for more names of statisticians to go to Cairo in the coming year (Scott to Cox, 23 May 1967, in Cox Papers). The Six-Day War began some two weeks later, as Bradley was returning to the US through Europe. The Ford office in Cairo closed as Americans evacuated the city, but when James Lipscomb

\footnotetext{
${ }^{37}$ So far, I have not been able to get access to - or even verify the existence of - documents at the ISSR that would shed light on these questions.
} 
returned in January 1968, the search for a new program specialist continued, now with Bradley's help (Ahmed Sarhan to James Lipscomb, 13 March 1968, Ford Archives, Grant \#639-504; Lipscomb to Kingsley, 4 April 1968, Ford Archives, Grant \#639-504).

Bradley continued to serve the ISSR and the Ford Foundation as a consultant to the Institute, visiting Cairo several times over the next decade, recruiting all but two of the remaining consultants, and writing the Foundation's final report when it closed out its grant to the ISSR in 1978. By then, the Institute had 16 full-time faculty, compared with just a single faculty member when it began in 1963 . These faculty made up four departments: applied statistics and economics, biostatistics and demography, computer science and operations research, and mathematical statistics. More than 300 students were enrolled in the 2-year diploma programs in statistics, computing science, demography, and operations research. The masters of science programs had 40 students, and ten students were progressing through the Ph.D. programs (Bradley 1978, Ford Archives).

The Ford Foundation had increased its original 1963 grant to the ISSR with two supplements, a second grant to establish a computing center affiliated with the Institute, and several smaller grants to subsidize conferences held at the ISSR. When John Hilliard proposed in 1963 that the Ford Foundation assist the ISSR, he speculated that Ford's support would total about $\$ 400,000$ over five years. In its fifteen years of funding, Ford ultimately provided $\$ 1.3$ million. ${ }^{38}$

In addition to supporting visiting statisticians, the original grant and its supplements purchased books and journals for the Institute's library and sent 24 Egyptian students abroad for graduate study, with the goal of increasing the Institute's faculty. By the time Bradley wrote his final report, 18 fellowship recipients had completed Ph.D.s, and eight of these were serving as faculty members at the ISSR. ${ }^{39}$ As Bradley described it, "the training record of ISSR students and doctoral programs abroad is remarkable." He felt that this aspect of the Ford program "must be judged successful," and that while more than half of Ford fellows were no longer at the Institute, "a contribution ha[d] been made" since most were serving elsewhere in the region (Bradley 1978, Ford Archives, 25). The library, for which Foundation support had been essential, had become "the leading library in Egypt in its areas of specialization" (ibid., 33).

Ford officials concurred with Bradley's assessment. When the final supplement to the grant had been made in 1973, the Cairo representative called the ISSR "the most important resource base in statistical training and research in the Middle East," and judged it to be "the most successful Foundation-sponsored activity in Egypt that ha[d] a truly regional impact" (James Ivy to Wayne Fredericks, 15 May 1973, Ford

\footnotetext{
${ }^{38}$ This final number comes from Richard C. Robarts to William D. Carmichael, 21 December 1978, Ford Archives, Grant \# 63-501. For the original estimate, see Hilliard to Ward, 6 February 1963, Ford Archives, Grant \# 63-501.

${ }^{39}$ Since completing Ph.Ds, 11 of the 18 had returned to the ISSR, but 3 of these had left by 1978 (Bradley 1978, Ford Archives, 19).
} 
Archives, Grant \#63-501). In his memorandum filed with Bradley's report, William D. Carmichael, head of the Middle East and Africa department of Ford's International Division, declared the grant a success, writing, “The Foundation's assistance responded to an important need. .., provided a well conceived mix of inputs. ., and was clearly essential ... for the survival and development of the Institute" (William D. Carmichael to Files, 9 June 1979, Ford Archives, Grant \#63-501). ${ }^{40}$

What had Gertrude Cox contributed to the success of this project? How did her work, her skills, and her passion for promoting statistics training shape the final outcome? Bradley's report, focusing primarily on the impact of the Ford Foundation more generally, does not assess the significance of individual program specialists. Cox's name appears on the list of consultants; Bradley notes her correspondence with Husein when the grant began and her recruitment of Marshall and Bradley; he briefly describes her activities while in Cairo and mentions that she discussed the needs of a computing facility while in Egypt. Otherwise, neither the report nor the comments on it by Foundation officials reveals the extent of her influence.

The fifteen years separating Cox's involvement and the end of the grant explain this omission, in part. By then, Ford had different staff both in the Cairo office and in the overseas office at its headquarters in New York. Back when she finished her time in Cairo, the verdict on her impact had been clear. "She has done an extraordinary job here in getting ISSR off to the best possible start," Lipscomb wrote to the New York office (Lipscomb to Scott, 18 May 1965, Ford Archives, Grant \#639-504). Echoing this praise in another memorandum, Lipscomb asserted, "Her professional reputation here is so high that I suspect she might be able to get some things done that most other program specialists or consultants we might provide could not" (Lipscomb to Kingsley, 15 September 1965, Ford Archives, Grant \#639-504). Carl Marshall remarked to Cox on the favorable impression she had made at the Institute. The Egyptians "love you and respect you in both the personal and professional sense," he reported. "I am sure they will not put all your recommendations ... into operation overnight, but you can rest assured that most of the improvements will be traceable to your efforts while you were here" (Marshall to Cox, 20 October 1965, in Cox Papers). ${ }^{41}$

At the most foundational level, Cox's efforts on behalf of the ISSR began with her creation of the Institute of Statistics in North Carolina. As Cox had described in her

\footnotetext{
${ }^{40}$ The ISSR exists today as a division of Cairo University, organized much as it was when Bradley wrote his report.

41 That her Egyptian colleagues would hold Cox in high regard, both personally and professionally, is consistent with other anecdotes about her personality and her relationships with colleagues (see, for example, Anderson 1979). As with the more general questions about Cox's success as a woman in a male-dominated field, the historical record reveals little about issues of gender and Cox's work in Egypt. The correspondence among ISSR staff, Ford officials, and Cox seem to contain no mention of gender-related tensions or any challenges she faced. The fact that the Egyptian constitution and laws changed under Nasser (president of Egypt from 1954 to 1970), giving women voting rights and increased access to employment and education may have played a role in Cox's experience, but these issues need further exploration.
} 
earliest conversations with Ford officials, some of the first statisticians in Egypt received their training at the Institute. Four of the 24 Foundation-sponsored fellows studied at UNC, and four of the twelve program specialists who followed Cox had received their Ph.D.s there, including Bradley and the two who followed him, Milton Terry and Lyle Calvin. Bradley and Calvin both helped create university statistics programs of their own - Bradley at Florida State University and Calvin at Oregon State University. Like Cox's North Carolina program, those at Florida State and Oregon State combined graduate training with consultation services to other university departments.

Cox's emphasis on the value of service to research workers in other departments (i.e., consulting) played an important role in the development of the ISSR. Initially, ISSR staff had little success in making consulting a central part of their work. Neither Marshall nor Bradley after him found many opportunities to use their abilities in this area. However, describing a recent conversation about consulting with an Institute faculty member, Marshall assured Cox, "I can see your handiwork in all these things and those seeds of ideas that you so masterfully planted are beginning to show signs of life" (Marshall to Cox, 7 October 1965, in Cox Papers).

While Bradley's verdict in his final report on the success of developing a statistical consulting service at the ISSR was negative, his report makes it clear that at least some interest in statistical consulting had continued from Cox's time to the present. As he put it, "The development of statistical consulting at ISSR has been slow and inadequate. Still an effort has been made and is continuing" (Bradley 1978, Ford Archives, 44). In fact, at the time of his report, Bradley was working with Calvin and an ISSR faculty member to get funding from the US Agency for International Development for a Statistical Consulting Service within ISSR (ibid.).

The slow pace at which consulting developed highlights the significance of Cox's efforts. As she reported while in Cairo, and as Bradley confirmed in his report, Cox had been "actively engaged in consulting within both Cairo University and the University of Alexandria and within government agencies and medical schools" (ibid., 42). In addition to seeking out consulting opportunities and involving her students in that work, Cox had emphasized the importance of providing such service in her report to the ISSR and Ford when she left. Later consultants, as Bradley puts it, "did do limited consulting on special requests but were less active in seeking opportunities" (ibid.). Though Bradley and his successors promoted statistical consulting less ardently than Cox had, interest at the ISSR persisted, perhaps in part because she had made service to other researchers a priority in her own work and in her advice to the Institute. $^{42}$

\footnotetext{
${ }^{42}$ According to Bradley, the slow pace at which consulting services developed was not unique to the ISSR, or even to programs in developing countries. "The provision of statistical advice and service to research in the various disciplines has been difficult to accomplish everywhere." Researchers outside of statistics had been slow to recognize the role of statistics because of "lack of training and insecurity in the use of statistics." Moreover, as Bradley described, "Many statisticians have been more interested in the development of statistical theory than in
} 
Finally, Cox's success in recruiting Carl Marshall and Ralph Bradley must be seen as critical for the success of the Ford Foundation grant. They maintained the momentum that Cox had initiated. Bradley played an important role in the ISSR's efforts to get Ford money for the computing center. Three ISSR fellowship recipients received Ph.D.s from his department at Florida State University. He continued giving advice to the Institute and recruiting visiting statisticians and computer scientists throughout the grant period. As a Ford official wrote in an internal memorandum when the grant ended, "The development of the ISSR owes much to Ralph Bradley" (Richard C. Robarts to William D. Carmichael, 21 December 1978, Ford Archives, Grant \#63-501). Bradley's connection to the ISSR owed much to Gertrude Cox.

Cox's affiliation with Cairo University, her work there, and her recommendations played an important role in the success of the Ford Foundation's grant. They also provide a glimpse of the passion and talent she had for promoting teaching and research in statistics. When she returned to the United States, Cox continued to exhibit that passion and talent. For the next four years, she taught experimental statistics (part time) at NC State, served as a senior statistical advisor to the Research Triangle Institute, and spent seven months in Thailand, advising universities as they developed their statistics education programs. ${ }^{43}$ She continued as the chair of the ISI Education Committee until 1968, and attended every ISI meeting through 1975, three years before her death from leukemia in 1978.

In the year following her time in Cairo, Cox gave several talks to students and faculty in university statistics departments. Her remarks suggest that her tenure at the ISSR had influenced her thinking about university statistics programs and had fueled her passion for serving others. Speaking at the North Carolina chapter of the ASA in April, 1966, Cox declared that "since returning from overseas, it almost seems as if I am starting on another campaign" (Cox 1996a, in Cox papers). In this talk and in subsequent addresses given over the next year, Cox called for some changes to university statistics courses. In particular, she advocated combining the teaching of statistical theory with statistical methods and analysis - subjects that usually appeared in separate courses. Echoing some of her advice to the ISSR, she also recommended supplementing the lectures with laboratory work, in which "students would become acquainted with real data and problems" (Cox 1966c, in Cox Papers). ${ }^{44}$

Along with her opinions about the teaching of statistics, Cox also displayed her passion for using one's knowledge to help others, and her belief that a good statistician could cooperate with researchers in other fields. "As you must know," she told her

the practice of statistics," believing that professional rewards were more likely to come from theoretical research (ibid.).

${ }^{43}$ Cox was in Thailand from December 1968 through January 1969 as a consultant with the Ford Foundation, and for six months in 1971 with the Rockefeller Foundation.

${ }^{44}$ Cox made a similar recommendation in the April 22 talk. These two talks as well as one given at a conference in August 1966 (cited below), overlap considerably. 
audience at the North Carolina ASA chapter meeting, "to be the kind of statistician I believe is needed so vitally, ... he must have the ability and willingness to cooperate with other scientists" (Cox 1966a, in Cox Papers). In another address, she emphasized that "the effectiveness of consulting statisticians is directly proportional to their ability and willingness to work with the people whom they assist. Statistical scientists have to forget themselves, be completely truthful and willing to share their knowledge" (Cox 1966b, in Cox Papers).

Back in Cairo, while commenting on the lack of attention given to consulting by ISSR statisticians and the fact that such work did not enhance one's professional status in Egypt, Cox had told her ISI colleague, Bart Lunenberg, "I'm not seeking local recognition nor advancement so it does not disturb me to serve my fellow men. My main objective is to serve the research workers and they appreciate the help" (Cox to Lunenberg, 19 April 1965, in Cox Papers). For Cox, this willingness to share knowledge not only benefited the recipients of the assistance, but the statisticians themselves. It not only advanced science, but provided personal satisfaction. She urged the graduate students in her audience to keep these ideas in mind as they began their careers. "Your ambition," she told them, "should be how much can I give, not how much can I get. Give and your storehouse of memories will overflow" (Cox 1966c, in Cox Papers). Cox's year at Cairo University was just one in a career of putting that advice into action.

\section{Conclusion}

This account of that year uncovers more than the talents, interests, and accomplishments of Gertrude Cox. By considering that year in a broader context, this case study helps illuminate important aspects of the development of statistics in particular, and of science more generally during the decades after World War II. It suggests that many of the questions guiding the study of the history of earlier periods and of other scientific disciplines are relevant here as well.

Some of these questions pertain to the development of statistics communities in the United States and abroad, and to the relationships among various national communities. In the first decades of the twentieth century, Americans regarded Britain as the center of statistical research - a place to obtain advanced training, as well as the source of the most important new research in the field. British researchers played leading roles in the creation and promotion of the tools of statistics and the mathematical theory behind them. Karl Pearson's work at University College, London, and Ronald A. Fisher's at Rothamsted Agricultural Experimental Station attracted students from around the world. ${ }^{45}$ By the 1960 s, statisticians in the United States had made a place

\footnotetext{
${ }^{45}$ For example, in an overview of statistical work in Britain published in 1930, Harold Hotelling wrote, "Modern statistical theory originated in England, and is today advancing faster there than in any other country" (Hotelling 1930, 186). For some details on Americans studying statistics in Britain, see Hunter 1999.
} 
for themselves in the international center. As Cox's experiences reveal, Americans now supplied much of the training to students from other countries; universities in developing countries looked to American institutions for models to emulate. What forces propelled this movement toward the center? What individuals and institutions played key roles? How was the production of knowledge in statistics shaped by the shift? What other national and international communities did the community in the United States influence? This case study shows that foundation funding and foreign aid policy of the United States shaped the role some American statisticians played on the international stage in the 1960s, particularly in developing countries. Even before the events described here, statisticians in the United States had been encouraged to contribute their expertise to the government's technical assistance programs created by Point IV. ${ }^{46}$ Further documentation of American statisticians' participation in these programs would shed light on one aspect of scientific exchange between the United States and other countries and would give a more detailed picture of the statistics community in the US in the second half of the century.

The emergence of mathematical statistics as a subfield of statistics had played a significant role in shaping the community in the 1920s. As mathematical statisticians created their own professional and institutional accoutrements, American scientists in academia began to treat statistics as an independent discipline. Subsequently, in the 1930s and 1940s, other subfields began to acquire journals, professional societies, and academic departments to support research. This account of Cox's work in Cairo demonstrates that the diversity of subfields within statistics was still playing a role in the development of the discipline after World War II. Consequently, answers to some of the questions guiding the history of mathematical statistics in the 1930s could be helpful for understanding the history of statistics in the decades after World War II. After the creation of the mathematical statistics community in the 1930s, what strategies did researchers in other subdisciplines use to encourage communication and obtain resources for their research? To what extent did the various subdisciplines compete for status and prestige? Did that competition play a role in the establishment of university statistics programs in countries trying to position themselves as equal players on the international scientific scene? Cox's correspondence with statisticians in the Middle East and Africa provides evidence that at least some of them were inclined to pursue programs that emphasized theoretical, mathematical statistics. Cox discouraged that emphasis, especially in research, believing that their work should concentrate on applications of statistical experiments and service to other sciences.

That concentration could position a new program (such as the ISSR's) to make a strong case for funding from the sponsors of technical assistance programs. These

\footnotetext{
${ }^{46}$ See for example, Hayes 1950, in which the author, then working at the State Department, informed his readers that "statistical training and advice in the collection and analysis of statistics is expected to be a major part of the technical programs undertaken by the United States and by the United Nations and its Specialized Agencies" (Hayes 1950, 5).
} 
sponsors, however, wanted to promote economic development, not establish university science programs for their own sake. To the extent that the tools of statistics could be used to improve food production, promote population control, and provide information about a country's resources, the Ford Foundation and other agencies saw some value in strengthening statistics training and research. Their support for university statistics programs was pragmatic, not an end in itself.

The improvement of national statistics research and teaching communities and the furtherance of scientific communication across national boundaries, then, were closely linked during this period with political and economic nationalism and internationalism. Some of the advocates of this improvement may have had interests that competed with, or at least stood in tension with each other. Similar links and tension existed in earlier efforts to promote the internationalization of science, though for different reasons and with different outcomes. For example, in his book on the Rockefeller Foundation's international grant-making in mathematics between the world wars, Reinhard Sigmund-Schultze describes the impact of one Rockefeller officer's "preconceptions as to the relation between scientific and political matters and as to the division of Europe into 'advanced' and 'backward' countries" (SiegmundSchultze 2001, 74). Augustus Trowbridge, head of the International Education Board (a Rockefeller philanthropy) in the 1920s, helped administer the Board's fellowship program, selecting students throughout Europe to study at premiere universities. Typically, and by design, fellowships went to the best students, with the goal of "making the peaks higher," but Trowbridge used some of the fellowships to develop science in what he called the "backward" countries (ibid., 64-69). For the period covered in this study, a more detailed exploration of the tensions between the Ford Foundation's agenda in its overseas work and the aspirations of the universities it helped would lead to a deeper understanding both of the Foundation and of the promotion of science in developing countries.

In addition to suggesting some answers to questions about the history of the statistics community in the United States, the internationalization of the statistics profession, and the connections and tensions between academic institutions and agencies such as the Ford Foundation and the UN, this case study uncovers some unexplored ground in the history of women in American science. The account of Cox's work for Cairo University prompts the natural question: "How did Cox achieve such influence, success and recognition, in spite of being a woman?" A more extensive analysis of Cox's career could help answer that question. It might, however, go beyond the obvious need to explain the exceptional, and address an alternative set of questions about women's roles in the promotion of statistics. To what extent did Cox's accomplishments result from her being a woman? Was she socialized and trained in such a way that she took on certain tasks essential to the promotion of the statistics profession more readily and skillfully than her male colleagues? How did the needs of the statistics profession - or of science more generally - in the decades after World War II align with the training and professional opportunities available to women and the expectations they had of themselves? 
After becoming chair of the ISI Education Committee, Cox spent months pursuing support for university statistics programs in Africa, work that fell outside her professional responsibilities and for which she received no pay. ${ }^{47}$ She met with Ford Foundation officials, recruited established statisticians to serve as consultants, and corresponded with statisticians who wanted help, trying to understand their institutional needs. None of the previous (male) chairs of the Education Committee had been so active. Very few new programs were aided under their leadership. Were they too busy pursuing work that more directly advanced their careers to take on the time-consuming and less rewarding labor of networking and lobbying? While in Cairo, Cox took on a heavy teaching and consulting schedule, aggressively pursuing opportunities to advise and serve - opportunities, again, that brought her no extra rewards. The subsequent (male) program specialists, as Bradley himself admitted, "were less active in seeking” consulting work, responding only to special requests from Egyptian researchers (Bradley 1978, Ford Archives, 42). ${ }^{48}$ Consequently, fifteen years after Cox's visit, statistical consulting at the ISSR was not adequately developed. Why did the men wait to be asked rather than seek opportunities to offer their services?

Cox's commitment to service helped both her own career and the statistics community as a whole. This case study, then, provides some new ways to think about the gendered nature of certain scientific activities and roles. It suggests that inverting the cause-and-effect or obstacle-and-accomplishment roles of gender and success can provide a useful tool for analyzing the experiences of women in science. That is, in addition to asking how an exceptionally successful woman overcame the typical obstacles to advancement in the male-dominated world of science, it may sometimes be helpful to consider the particularly "feminine" qualities that her male colleagues lacked, but that contributed to her success.

These questions point to somewhat different issues than those surrounding Rossiter's discussion of "women's work" in science (Rossiter 1982, chap. 3). Cox's work was neither invisible nor segregated. She not only worked with male colleagues, but held positions of authority over them. Her contemporaries readily credited her with advancing the discipline, though she did not earn her accolades primarily by proving theorems or otherwise directly producing knowledge in the field. She was doing high profile work that everyone acknowledged as important, but not doing it, she claimed, for recognition or advancement. She saw a need for statisticians with ambition to give, not to get; with a willingness to share their knowledge with others, serving their "fellow men." If, as Cox believed, the statistics community needed such people in the 1960s,

\footnotetext{
${ }^{47}$ Recall her comment to a Research Triangle Institute colleague about the Ford contract "giving status" to her ISI work.

${ }^{48}$ For a clear understanding of this difference between Cox and the subsequent program specialists, it is important to note that they did not seem to have less regard for the importance of consulting. For example, as mentioned above, at the time of his final report to Ford, Bradley was working on a grant proposal to support consulting at the ISSR.
} 
perhaps women like Cox were even better equipped than their male colleagues to fill the role. Moreover, this component of Cox's success may have implications beyond the issues of gender introduced here. A broader investigation into the work of statisticians who participated in technical assistance to developing countries during this period might find that the most successful had a willingness to set aside the advancement of their own careers in favor of service to the broader community.

The record of Cox's contributions to the ISSR in Cairo certainly reveals that she had the skills and knowledge to play a crucial role in its development. The analysis of that record indicates that the ISSR, the Ford Foundation, and the statistics community in the United States were part of a much larger web of institutions impacting the international development of the discipline. This case study has uncovered some features of that network and proposed some theses about the institutions involved. It has also raised further questions, suggesting lines of research that, if pursued, would add significantly to our understanding of the history of science after World War II.

\section{Unpublished References}

\section{Gertrude Mary Cox Papers, MC 117, Special Collections Research Center, North Carolina State University Libraries, Raleigh, North Carolina}

Cox et al. 1946. "Resolution," 7 August.

Cox, Gertrude M. 1953. "The Role of Statistics in Research."

Cox, Gertrude M. 1963. "Statistical Education in Africa," 24 August.

Cox, Gertrude M. 1965a. "Choosing an Experiment Plan."

Cox, Gertrude M. 1965b. "Fascination of Statistics."

Cox, Gertrude M. 1965c. "Suggestions on Long Range Plans for Institute of Statistical Studies and Researches."

Cox, Gertrude M. 1966a. "Education in Statistics," 22 April.

Cox, Gertrude M. 1966b. "Past, Present and Future Developments in Statistics in the Southern Region."

Cox, Gertrude M. 1966c. "Status of Training in Statistics in Developing Countries," 28 February.

\section{Personal Files of Helena Hoen Caffrey}

Cox, Gertrude M. n.d. "Foreign Countries Visited."

Cox, Gertrude M. 1977. "Personal History Record."

\section{Personal Files of Karldene Marshall Cleveland}

Marshall, Carl E. 1992. "My Memoirs."

\section{Archives of the International Statistical Institute}

International Statistical Institute. 1955. Minutes of the Meeting of the Statistical Education Committee, 27 June. 
International Statistical Institute. 1957. Minutes of the Joint Meeting of the Bureau and the Statistical Education Committee, 12 August.

International Statistical Institute. 1958. Minutes of the Meeting of the Statistical Education Committee, 8 September.

\section{Ford Foundation Archives}

Bradley, Ralph A. 1978. "Ford Foundation Grants to the Institute of Statistical Studies and Research, Cairo University 1963-1978, A Final Report.” 10 April. Grant \# 63-501.

\section{Published References}

Annals of Mathematical Statistics. 1953. "News and Notices.” Annals of Mathematical Statistics 24:313-18. Anderson, Richard L. et al. 1979. "Gertrude M. Cox - A Modern Pioneer in Statistics." Biometrics 31:3-7.

Anderson, Richard L. 1980. "William Gemmell Cochran 1909-1980: A Personal Tribute." Biometrics 36:574-78.

Anderson, Richard L. 1990. "Gertrude Mary Cox, 1900-1978." National Academy of Sciences Biographical Memoirs 59:117-32.

Anscombe, Francis J. 1988. “Frederick Mosteller and John W. Tukey: A Conversation.” Statistical Science 3:136-144.

Bancroft, Theodore A. 1982. "Roots of the Iowa State University Statistical Center: 1914-1950." Iowa State Journal of Research 57:3-10.

Berman, Edward H. 1983. The Ideology of Philanthropy: The Influence of the Carnegie, Ford, and Rockefeller Foundations on American Foreign Policy. Albany: State University of New York Press.

Board of Trustees. 1962. The Ford Foundation in the 1960s. New York: Ford Foundation.

Cochran, William G. and Gertrude M. Cox. 1950. Experimental Designs. New York: John Wiley.

Cox, Gertrude M. and Paul G. Homeyer. 1975. "Professional and Personal Glimpses of George W. Snedecor." Biometrics 31:265-301.

Crawford, Elisabeth, Terry Shinn, and Sverker Sörlin. 1993. "The Nationalization and Denationalization of the Sciences: An Introductory Essay." In Denationalizing Science: The Contexts of International Scientific Practice, edited by Elisabeth Crawford, Terry Shinn, and Sverker Sörlin, 1-42. Dordrecht: Kluwer.

Ford Foundation. 1951. Annual Report. New York: Ford Foundation.

Gaither, Jr., H. Rowan, et al. 1949. "Report of the Study for the Ford Foundation on Policy and Program.” Detroit: Ford Foundation.

Gani, Joseph. 1979. "The Role of ISI in the Field of Statistical Education: 1949-1979." International Statistical Review 47:237-244.

Goudswaard, Gijsbert. 1964. "A Re-appraisal of the Statistical Education Programme of the International Statistical Institute." Review of the International Statistical Institute 32:88-103.

Grier, David A. 2005. When Computers Were Human. Princeton: University Press.

Hahn, Peter L. 1991. The United States, Great Britain, and Egypt, 1945-1956: Strategy and Diplomacy in the Early Cold War. Chapel Hill: University of North Carolina Press.

Hayes, Jr., Samuel, P. 1950. "Statistics in the Point IV Program." American Statistician 4:4-5.

Hotelling, Harold. 1930. "British Statistics and Statisticians Today." Journal of the American Statistical Association 25:186-90.

Hotelling, Harold. 1940. "The Teaching of Statistics.” Annals of Mathematical Statistics 11:457-72.

Hunter, Patti W. 1996. "Drawing the Boundaries: Mathematical Statistics in Twentieth-Century America." Historia Mathematica 23:7-30. 
Hunter, Patti W. 1997. "The Formation of a Discipline: Mathematical Statistics in the United States in the Nineteenth and Twentieth Centuries." Ph.D. diss., University of Virginia.

Hunter, Patti W. 1999. "An Unofficial Community: American Mathematical Statisticians before 1935." Annals of Science 56:47-68.

International Statistical Institute. 1933. "Extrait des Statuts de L'Institut International de Statistique." Review of the International Statistical Institute 1: n.p.

International Statistical Institute. 1949. "Furtherance of Statistical Education." Review of the International Statistical Institute 17:1-34.

International Statistical Institute. 1957. "Report of the Bureau to the 30th Session of the International Statistical Institute." Review of the International Statistical Institute 25:222-236.

Kohler, Robert E. 1991. Partners in Science: Foundations and Natural Scientists, 1900-1945. Chicago: University of Chicago Press.

Larrabee, Charles. X. 1991. Many Missions: Research Triangle Institute's First 31 Years. Research Triangle Park, NC: Research Triangle Institute.

Latham, Earl. 1946. "One Statistical World.” Journal of the American Statistical Association 4:275-92.

Lulat, Y. G-M. 2005. A History of African Higher Education from Antiquity to the Present. Westport, Conn.: Praeger.

Lush, Jay L. 1972. "Early Statistics at Iowa State University." In Statistical Papers in Honor of George W. Snedecor, edited by Theodore A. Bancroft, 211-226. Ames: Iowa State University Press.

Madow, William G. 1960. "Harold Hotelling." In Contributions to Probability and Statistics: Essays in Honor of Harold Hotelling, edited by I. Olkin et al., 3-5. Stanford: University Press.

Neyman, Jerzy. 1960. "Harold Hotelling - A Leader in Mathematical Statistics." In Contributions to Probability and Statistics: Essays in Honor of Harold Hotelling, edited by I. Olkin, 6-10. Stanford: University Press.

Nixon, James W. 1960. A History of the International Statistical Institute: 1885-1960. The Hague: International Statistical Institute.

Nourse, E. Shepley and Bernard G. Greenberg. 1978. "Statistical Training and Research: The University of North Carolina System." International Statistical Review 46:171-207.

Ntozi, James P. M. 1992. "Training of African Statisticians at a Professional Level." Journal of Official Statistics 8:467-79.

Packenham, Robert A. 1973. Liberal America and the Third World: Political Development Ideas in Foreign Aid and Social Science. Princeton: Princeton University Press.

Parshall, Karen H. and Adrian Rice, eds. 2002. Mathematics Unbound: The Evolution of an International Mathematical Research Community, 1800-1945. Providence, R.I.: American Mathematical Society/London: London Mathematical Society.

Rao, Poduri S. R. S. and Joseph Sedransk, eds. 1984. W. G. Cochran's Impact on Statistics. New York: John Wiley.

Rice, Stuart A. 1947. "Announcement to Members." Review of the International Statistical Institute 15:13769.

Rietz, Henry L. and Arthur Crathorne. 1926. "Mathematical Background for the Study of Statistics." Journal of the American Statistical Association 21:435-440.

Rossiter, Margaret W. 1982. Women Scientists in America: Struggles and Strategies to 1940. Baltimore: Johns Hopkins University Press.

Rossiter, Margaret W. 1995. Women Scientists in America: Before Affirmative Action, 1940-1972. Baltimore: Johns Hopkins University Press.

Ryan, Walter F. 1982. "In Memoriam: William Ramsdell Leonard, 1904-1981." American Statistician 36:122-123.

Sarhan, Ahmed E. 1957. "Teaching of Statistics in Egypt." American Statistician 11:15-17.

Siegmund-Schultze, Reinhard. 2001. Rockefeller and the Internationalization of Mathematics between the Two World Wars. Basel: Birkhäuser Verlag. 
Snedecor, George W. 1936. "The Improvement of Statistical Techniques in Biology." Journal of the American Statistical Association 31:690-701.

Snedecor, George W. and Gertrude M. Cox. 1935. "Disproportionate Subclass Numbers in Tables of Multiple Classification." Iowa Agricultural Experiment Station Research Bulletin.

Wilson, Louis R. 1964. The University of North Carolina under Consolidation, 1931-1963: History and Appraisal. Chapel Hill: University of North Carolina Consolidated Office. 